\title{
Methicillin-resistant Staphylococcus aureus in food and the prevalence in Brazil: a review
}

\author{
Anderson Clayton da Silva ${ }^{1}$ (D) $\cdot$ Marjory Xavier Rodrigues ${ }^{2} \cdot$ Nathália Cristina Cirone Silva $^{1}$
}

Received: 31 January 2019 / Accepted: 9 October 2019/Published online: 30 October 2019

(C) Sociedade Brasileira de Microbiologia 2019

\begin{abstract}
Foodborne diseases (FBD) occur worldwide and affect a large part of the population, being a cause of international concern among health authorities. Staphylococcus aureus can be transmitted by contaminated food, and it is one of the pathogens that most cause foodborne outbreaks in Brazil. Currently, this organism's ability in developing resistance to antibiotics is notorious; methicillin-resistant Staphylococcus aureus - MRSA — is known for its resistance to methicillin, oxacillin, and others. MRSA is one of the leading causes of infections, becoming a major threat to human health worldwide due to the numerous toxins that can produce. At first, the transmission of MRSA occurred in clinical environments; but in recent decades, its presence has been reported in the community, outside the hospital environment, including food and food-producing animals around the world. In this review, information about MRSA was gathered to verify MRSA incidence in the world but especially in Brazil in food samples, food handlers, food-producing animals, and food processing environments. The studies show that MRSA is easily found and in certain cases with high frequency, thus representing a potential risk to public health.
\end{abstract}

Keywords Brazil $\cdot \mathrm{FBD} \cdot \operatorname{mec} \mathrm{A} \cdot \mathrm{MRSA} \cdot$ Oxacillin

\section{Introduction}

Foodborne diseases (FBD) occur worldwide and affect a large part of the population, being a cause of international concern among health authorities [1]. FBDs have significant morbidity and mortality, it is estimated that thousands of people are hospitalized and some of them die from this cause. It is very difficult to estimate the actual number of FBD cases because not all of them are registered by the public health system due to misdiagnosis or underreporting [1].

Staphylococcus aureus can be transmitted by contaminated food [2]; and it is one of the pathogens that most cause foodborne outbreaks in Brazil [3]. This transmission is mainly

Responsible Editor: Mariza Landgraf.

Nathália Cristina Cirone Silva

ncirone@unicamp.br

1 Department of Food Science, Faculty of Food Engineering (FEA), University of Campinas (UNICAMP), Rua Monteiro Lobato, Campinas, SP, Brazil

2 Department of Population Medicine and Diagnostic Sciences, College of Veterinary, Medicine Cornell University, Campus Road, Ithaca, NY, USA due to the poor handling of food during processing $[4,5]$. The consumption of food contaminated with toxins produced by S. aureus can lead to staphylococcal food poisoning, which may cause severe gastroenteritis, nausea, vomiting, diarrhea, and abdominal pain within 1 to $6 \mathrm{~h}$ after the consumption of contaminated food [6]. S. aureus can also lead to other diseases [2]; some of them severe, such as sepsis, endocarditis and necrotizing pneumonia [7]. This bacterium is found on human skin and it is commonly identified as a cause of hospital-acquired infections [8]. It is also the leading cause of bacterial infections in humans; around $20 \%$ of humans are persistent carriers of $S$. aureus, $30 \%$ are intermittent carriers, $50 \%$ of people do not carry this bacterium $[7,9,10]$, and a third of people are asymptomatic carriers; the pathogen is commonly found in the nostrils, neck, axillae, groin, and rectum [11-13].

$S$. aureus spp. are non-spore forming Gram-positive bacteria in the form of cocci; they are non-mobile, mesophilic, biofilm-forming, and facultative anaerobes that produce enterotoxins [3]. They were first described by Sir Alexander Ogston in 1881, when the infection caused by this agent was fatal because of the lack of antibiotics [11]. Currently, this microorganism's ability in developing resistance to antibiotics is notorious. The resistance is usually acquired by horizontal 
gene transfer, although mutation and selection are also important [14]. Infections caused by resistant strains are common in epidemic waves by one or more clones; methicillin-resistant Staphylococcus aureus (MRSA) is prominent in epidemic waves, being historically associated with hospitals and health units (healthcare-associated MRSA (HA-MRSA). Nowadays, it has emerged as a cause of community-associated infections (CA-MRSA), spreading rapidly among healthy individuals and its presence is a cause of concern due to resistance to various antibiotics, limiting treatment [14].

The incidence of CA-MRSA has been increasing [15-18]. Furthermore, CA-MRSA strains appear to be especially virulent [14]. It should be noted that CA-MRSA, HA-MRSA, and livestock-associated MRSA (LA-MRSA) have been found in foods intended for human consumption [15]. Researches have been showing the incidence of MRSA isolated from foods $[6$, 9, 19-21]. Studies from different geographical areas have revealed the presence of enterotoxins in MRSA isolates; in addition, the genetic relationship between enterotoxigenic isolates and isolates from human infections has been reported [15]. Therefore, this review aims to explore data that show the importance and incidence of MRSA isolated from foods around the world, and especially in Brazil where $S$. aureus is one of the main etiological causes of food poisoning outbreaks.

\section{Antibiotic-resistant Staphylococcus spp.}

Antibiotics correspond to a group of drugs that are commonly used in hospitals and in the community. However, pharmacological agents do not only affect the patients that use this, but also significantly intervene in the environment through the genetic modification of microorganisms [22].

The use of antibiotics has increased a lot over the years and, consequently, the exposure of these medicines to bacteria has also expanding [23]. S. aureus is a bacterial species known for its ability to become resistant to antibiotics [14]. For Chambers and DeLeo [14], exposure to antibiotics was, without a doubt, the most concentrated selective pressure exerted on the co-evolutive history of $S$. aureus with humanity.

The indiscriminate use of antibiotics stimulates the development of antibiotic resistance. The most useful antibiotics in the treatment of infections caused by $S$. aureus are $\beta$-lactams, including penicillin, methicillin, flucloxacillin, dicloxacillin, nafcillin, oxacillin, and cloxacillin [24].

Methicillin-resistant S. aureus (MRSA) are those who carry the mecA gene and are resistant to all penicillins, cephalosporins,s and carbapenem [24]. In MRSA cases, the antibiotic of choice has for a long time been vancomycin; however, other options have emerged such oxazolidinones, glycylcyclines, and lipopeptides [25]. Nevertheless, it is relevant to describe how antibiotic-resistant $S$. aureus arose, especially MRSA.
In 1928, Alexander Fleming discovered penicillin, thus making it possible to treat infections caused by S. aureus, starting the "Antibiotic Era" [14]. However, the use of penicillin to treat infections did not last long, as penicillin-resistant strains started to emerge [11]. In 1940, S. aureus became resistant to sulfonamide, and in 1944, it started becoming resistant to penicillin [11]. Thus, epidemic waves of antibiotic-resistant $S$. aureus began; in the 40s, the first wave was observed with resistance to penicillin, which still occurring today [14]. Methicillin and oxacillin were used in the 1960 s to treat infections caused by S. aureus; however, some years later, resistant strains emerged, which were collectively known as MRSA [25]. In the following years, cases of resistance of $S$. aureus to different classes of antibiotics such as macrolides, fluoroquinolones, glycopeptides, aminoglycosides, and tetracyclines started being reported [26]. The second wave occurred almost immediately after the introduction of methicillin with the isolation of the first MRSA isolate, type I SCCmec (Staphylococcal Cassette Chromosome mec) [14]. The third wave happened in the mid-1970s with new MRSA strains that had new SCCmec types, type II and III, signaling a MRSA pandemic around the world; and the fourth and latest wave of antibiotic resistance arose in the late 1990s, with the emergence of MRSA strains in the community [14]. The discovery of CA-MRSA happened in the USA [27] when the strains were already resistant to several antibiotics, in addition to those of the beta-lactam type, and were not related to the hospital strains, which contained a new SCCmec, type IV, and a variety of virulence factors [14]. With the increase in MRSA, the use of vancomycin also increased in the treatment of infections caused by these bacteria; in this way, strains with intermediate resistance to vancomycin (Vancomycin-intermediate Staphylococcus aureus (VISA)) emerged, and in 2002, the first strains resistant to vancomycin (Vancomycin-Resistant Staphylococcus aureus (VRSA)) were identified [14].

Given the above, the concern about the presence, distribution, and incidence of resistant strains in any environment becomes evident; especially in health units where weakened individuals may be exposed to them, and in food production, where people from different age groups and with different health states may be contaminated during production and/or consumption.

\section{Methicillin-resistant Staphylococcus aureus}

The MRSA is one of the leading causes of infections [28]; $50 \%$ of the strains isolated in the USA and in European countries are Methicillin-resistant $[25,29]$. Infections caused by MRSA generate higher expenses in the area of public health, and higher morbidity and mortality rate compared with nonresistant strains $[25,30]$. Additionally, infectious diseases caused by MRSA are among the leading causes of death caused by infectious agents [11]. 
More people die each year from infections caused by MRSA than by HIV (human immunodeficiency virus) in the USA [11]. Thereby, methicillin resistance is a very serious health problem when implicated in human infections or in animals [31]. It is worth noting that the rapid detection of the infection may contribute to the effectiveness of treatment and reduction in the mortality rate $[32,33]$.

Currently, MRSA is spread around the world and its ability to acquire antibiotic resistance mechanisms raises concern; MRSA is often or can easily become resistant to multiple antibiotics, limiting treatment options [14]. At first, the transmission of MRSA occurred in clinical environments, but in recent decades, its presence has been reported in the community, outside the hospital environment [7]. However, investigating the origins of bacteria is complicated. Evidence indicates that resistant $S$. aureus can be spread in livestock operations and in hospitals, where antibiotics are widely used; thus, it could be disseminated within communities and the environment. It is worth mentioning that more researches are essential to determine how the transfers in fact occur [34].

As mentioned above, MRSA is classified as HA-MRSA, healthcare-associated methicillin-resistant $S$. aureus, CAMRSA, community-associated methicillin-resistant $S$. aureus [35], or LA-MRSA, livestock-associated methicillin-resistant S. aureus. In an even more worrisome scenario, MRSA strains may become resistant to multiple antibiotics (multidrugresistant MDR) [25]. The biggest problem is the ability of these bacteria to be transferred from animals to humans, causing infections [36]. Reports have been mentioned MRSA in animals, especially in pigs, but it can also affect calves [37], horses [38], and dogs [39]. LA-MRSA can be transmitted to humans who live in close contact with animals [40]. S. aureus can also be transmitted to humans through meat products, for example, due to their improper handling or crosscontamination during processing [34]. A recent study by Caggiano et al. [40] assessed healthy individuals who worked in the food industry, and the presence of $S$. aureus and MRSA among the individuals represented a risk to public health. LAMRSA strains have been found in pork and chicken products in the USA, as well in raw turkey meat [34]. Caggiano et al. [40] conclude that the spread of S. aureus and MRSA in nonhospital environments, such as communities and in livestock, demands careful and continuous monitoring.

There are several methods to determine whether a $S$. aureus strain is methicillin-resistant; however, the one that is most often employed is the Kirby-Bauer method, which uses oxacillin and cefoxitin [25]. However, conventional culturing methods demand a lot of time; thus, methods based on polymerase chain reaction (PCR) and hybridization assays have been increasingly used as rapid methods for detection of MRSA [41]. The combination of methods has been widely employed for the detection of MRSA.

\section{Resistance mechanism}

The mecA gene, responsible for methicillin resistance in $S$. aureus, is the reason for these groups of microorganisms to be considered resistant to all beta-lactam antibiotic [42]. Methicillin resistance in $S$. aureus is mediated by the mecA gene, which encodes a new penicillin-binding protein (PBP), PBP-2a [43]. In MRSA strains, exposure to methicillin renders the four high-affinity binding proteins (PBPs) present inactive, whereas PBP-2a has low affinity to methicillin, allowing the growth of the cell, because it assumes the functions of the PBPs [43]. This resistance allows the biosynthesis of the cell wall, which is the target of $\beta$-lactam antibiotics, and occurs even in the presence of often inhibitory concentrations of antibiotics [44]. The regulation of the phenotype of resistance to methicillin and the production of PBP-2a are carried out by other genes, mecR1 and mecl; in addition, antibiotics with high PBP-2a affinity have shown effectiveness against MRSA in vivo [43].

These binding proteins decrease the ability of $\beta$-lactam antibiotics to act on bacteria [45]. In addition to the mecA gene, the mec $\mathrm{C}$ gene (previously called mecLGA251) has been recently described. This gene has been identified in strains isolated from, for example, milk collected from 465 herds in England in 2007 [46], and in cattle that would be submitted to slaughter between October 2011 and January 2012, mainly in Belgium and in France [47].

The resistance mechanism acquired by $S$. aureus can be divided in two categories: the mutation of a bacterial gene in the chromosome or the acquisition of a resistance gene from other bacteria through genetic exchange (conjugation, transduction, or transformation) [48].

The mobile genetic elements are related to PBP-2a, the penicillin-binding protein encoded by the mecA gene, which is found in SCCmec, the genetic element that encodes methicillin resistance; the resistance expression is controlled through transduction by a proteolytic signal, which corresponds to a sensor protein $(m e c \mathrm{R} 1)$ and a repressor $(\mathrm{mecl})$ [44]. Molecular and biochemical mechanisms concerning methicillin resistance in $S$. aureus have been subject of studies, including regulatory events and those related to the structure of proteins [44].

The type of SCCmec can confer resistance to multiple antibiotics $[13,49,50]$. It transports site-specific recombinases, called cassette chromosome recombinases ( $\mathrm{ccr}$ ), which are responsible for the mobility of the elements. In S. aureus, three types of ccr genes have already been identified, $c c r \mathrm{~A}, c c r \mathrm{~B}$, and $c c r \mathrm{C}$ [51].

It is important to understand the origin and evolution of MRSA clones. The acquisition and diversity of different SCCmecs are crucial [52], and it is through that methicillinsusceptible $S$. aureus (MSSA) becomes MRSA. SCCmec carries either the mecA or mec $\mathrm{C}$ gene, regulatory genes, $c c r \mathrm{AB}$ or/and $c c r \mathrm{C}$ site-specific recombinase genes, and a variety of accessory genes encoding for a new specific 
penicillin-binding protein (PBP2a) [53, 54]. The SCCmec element contains three $\mathrm{J}$ regions, besides the $m e c$ and $c c r$ gene complexes, they were first report as the L-C, C-M, and I-R regions but were later changed to $\mathrm{J}$ regions. These regions constitute non-essential components of the cassette and may carry additional antimicrobial resistance determinants [55].

According to International Working Group on the Staphylococcal Cassette Chromosome elements (IWGSCC), there are 11 official types of SCCmec recognized [56]. Some studies even mention the existence of 12 SCCmec [54] or even 13 SCCmec [52]. Traditionally, types I to III have been associated with MRSA strains from clinical isolates, while community (CA-) or livestock-associated (LA-) strains tend to harbor smaller and supposedly more mobile type IV SCCmec types and V [57, 58]. But it is currently possible to find several types of Staphylococcus SCCmec isolated from different types of food $[21,59,60]$.

\section{Methods used for identification and characterization of MRSA}

There are several methods for identification of MRSA strains, phenotypically or genotypically. Strains can be screened on MRSA agar, after 18 to $24 \mathrm{~h}$ of incubation at $37^{\circ} \mathrm{C}$, colonies that appear pink are considered MRSA [59]. Other typical way are Kirby-Bauer standard disk-diffusion methods, which are commonly used to determine antimicrobial susceptibility according to the Clinical and Laboratory Standards Institute (CLSI) guidelines $[25,59,61-63]$ or even the broth microdilution technique [64].

Some studies use resistance to oxacillin $[59,65]$ or cefoxitin [62,64] or both [25] to determine if the strain is MRSA. It is also possible to determine MIC of $S$. aureus strains by the $E$-test according to the protocol suggested by the manufacturer [61].

Identification by polymerase chain reaction (PCR) $[41,59$, 62-68] is also widely used. Specie confirmation can be performed using nuc gene; mecA gene is used to identify the methicillin-resistant strain [59, 62, 63, 65, 67, 68]. Other alternative for detection of MRSA is the use of kits based on PCR, a multiplex PCR and real-time PCR, to detect each SCCmec type and the chromosomal orfX-SCCmec junction [69]. In some cases when $S$. aureus is resistance to cefoxitin but is negative for the mecA gene, they can be tested for $m e c \mathrm{C}$ gene, which also characterizes $S$. aureus as MRSA [67].

After confirmation of the mecA gene, it is important to submit the strains to additional molecular characterization. The techniques that are generally used are as follows: staphylococcal protein A (spa) typing [59, 61, 66-68], multilocus sequence typing (MLST) [59, 61, 64, 66, 67, 70], pulsed field gel electrophoresis (PFGE) [64-66], Staphylococcal cassette chromosome mec (SCCmec) typing [59, 66].

\section{Methicillin-resistant Staphylococcus aureus isolated from food}

MRSA has already been isolated from food, indicating that they are present as contaminants in the food production chain $[6,51,71]$. Recently, studies have been performed focused on transmission of MRSA, since its diffusion among foodproducing animals and food has increased [2, 7, 72, 73].

The presence of this group of microorganisms was reported mainly in meats such as pork, beef, lamb, chicken, rabbit, and turkey, and also in dairy products, e.g. milk and cheese [51]. This means that the food production chain is a channel of transmission between resistant microorganisms and humans [4]. In this way, the monitoring of genetic characteristics of MRSA is important to better understand its genetic evolution [72].

The following table presents a data survey on studies conducted in different countries where MRSA was isolated from various kinds of food.

As shown in Table 1, a survey of MRSA research over the past 16 years has shown a great occurrence of this type of bacteria in meat, milk, and dairy products, becoming increasingly clear that MRSA is more present in products of animal origin or food-producing animals.

\section{MRSA in Brazil}

The data survey on the incidence of MRSA in food has been happening also in Brazil. Researches in different regions have been showing the incidence of MRSA in food and foodproducing animals, with an emphasis on milk and dairy products and meat and meat products. Furthermore, the importance of researches conducted with samples of food processing environments and food handlers should also be highlighted [65, 89, 90]. Next, studies shall be presented to demonstrate the incidence of $S$. aureus and specifically MRSA in Brazilian territory. $S$. aureus is still a common contaminant in food in Brazil; it has been reported as one of the most prevalent causes of FBD in the country according to the Secretary of Health Surveillance [91], and it is commonly identified as the cause of diseases in food-producing animals.

In the Northeast of the country, Soares et al. [92] analyzed the presence of $S$. aureus in samples of food handlers in public schools of Camaçari, Bahia State. Swabs were collected out of the hands of 166 handlers, $53.3 \%$ of the samples were positive for the presence of $S$. aureus. The results indicated that the food handlers were using inadequate sanitary practices and rethink their training to ensure proper hygiene was essential [92]. Still in the Northeast, a study by Ferreira et al. [93] aimed to evaluate the presence of MRSA in food handlers of public hospitals in the city of Salvador, Bahia. The researchers collected swabs from the nostrils and hands of 140 food handlers in 10 public hospitals; $50 \%$ of the handlers had S. aureus on their hands or nostrils and $28.6 \%$ had MRSA. These authors 
Table 1 Incidence of methicillin-resistant Staphylococcus aureus (MRSA) in foods in different countries

\begin{tabular}{|c|c|c|c|c|c|}
\hline Number of sample & Number of isolated & MRSA & Sample & Origin & Reference \\
\hline $\mathrm{N} / \mathrm{M}$ & 846 & $5(0.6 \%)$ & Cow milk & Michigan, USA & {$[74]$} \\
\hline $\mathrm{N} / \mathrm{M}$ & 2132 & $38(1.8 \%)$ & Cow milk & Wisconsin, USA & {$[75]$} \\
\hline 444 & 292 & $2(0.7 \%)$ & Chicken & Japan & {$[76]$} \\
\hline $\mathrm{N} / \mathrm{M}$ & 357 & $0(0 \%)$ & Cow milk & North Carolina and Virginia, USA & {$[77]$} \\
\hline 1260 & 157 & $30(19.1 \%)$ & Mutton, beef, camel, and poultry & Jordan & {$[78]$} \\
\hline 79 & 36 & $2(5.5 \%)$ & Pork and raw beef & Holland & {$[79]$} \\
\hline 1634 & 160 & $6(3.8 \%)$ & Cow milk and cheese & Italy & {$[80]$} \\
\hline 318 & $\mathrm{~N} / \mathrm{M}$ & $5(1.6 \%)$ & $\begin{array}{l}\text { Pork, chicken, rabbit, veal, } \\
\text { and wild boar }\end{array}$ & Spain & {$[81]$} \\
\hline 2217 & $\mathrm{~N} / \mathrm{M}$ & $264(11.9 \%)$ & $\begin{array}{l}\text { Beef, veal, lamb and mutton, } \\
\text { pork, chicken, turkey, poultry }\end{array}$ & Netherlands & {$[82]$} \\
\hline 79 & 36 & $2(5.5 \%)$ & Retail meat & Holland & [9] \\
\hline 120 & 47 & $6(12.8 \%)$ & Retail meat & USA & \\
\hline $\mathrm{N} / \mathrm{M}$ & 402 & $31(7.7 \%)$ & Retail meat & Canada & \\
\hline 583 & $\mathrm{~N} / \mathrm{M}$ & $\begin{array}{l}1(0.2 \%) \\
13(26.5 \%)\end{array}$ & $\begin{array}{l}532 \text { human swabs without direct } \\
\text { contact with pig breeding and } 49 \\
\text { with direct contact }\end{array}$ & Netherlands & {$[19]$} \\
\hline 86 & $\mathrm{~N} / \mathrm{M}$ & $32(37.2 \%)$ & $\begin{array}{l}\text { Chicken, chicken meat products, } \\
\text { turkey, turkey meat products }\end{array}$ & Germany & {$[83]$} \\
\hline 256 & $\mathrm{~N} / \mathrm{M}$ & $26(10.15 \%)$ & Pork & USA & {$[84]$} \\
\hline NM & 583 & $28(4.8 \%)$ & Wild boar meat & Berlin, Germany & {$[64]$} \\
\hline 100 & 7 & $2(28.6 \%)$ & Fish-based ready-to-eat food & Greece & {$[85]$} \\
\hline 383 & 35 & $7(20 \%)$ & Raw milk & Italy & {$[86]$} \\
\hline 323 & 85 & $7(8.2 \%)$ & Nasal swabs of food industry workers & Italy & {$[40]$} \\
\hline 195 & 54 & $16(29.6 \%)$ & Raw milk & China & {$[87]$} \\
\hline 93 & 54 & $19(35,2 \%)$ & Clinical mastitis milk & Cairo, Egypt & {$[63]$} \\
\hline 3760 & 484 & $40(8.3 \%)$ & Milk and milk derivatives & Italy & {$[59]$} \\
\hline 3290 & 913 & $41(4.5 \%)$ & Raw meat & Iowa, USA & {$[88]$} \\
\hline $\mathrm{N} / \mathrm{M}$ & 24 & $9(37.5)$ & Milk & Switzerland and Italy & {$[68]$} \\
\hline 147 & 40 & $2(5 \%)$ & Milk and swab & Brazil & {$[65]$} \\
\hline $\begin{array}{l}372 \\
303\end{array}$ & $\begin{array}{l}\mathrm{N} / \mathrm{M} \\
\mathrm{N} / \mathrm{M}\end{array}$ & $\begin{array}{l}36(9.7 \%) \\
5(1.7 \%)\end{array}$ & $\begin{array}{l}\text { Bulk tank milk from conventional } \\
\text { Bulk tank milk from organic }\end{array}$ & Germany & {$[67]$} \\
\hline
\end{tabular}

$N / M$, not mentioned

also concluded that there is great deficiency in the hygiene of food handlers, which could cause infection in patients [93].

André et al. [94] held in Goiânia a study conducted from February 2004 to March 2005, in which 24 milk samples, 24 samples of Minas Frescal cheese, and 92 samples of food handlers (46 of their hands and 46 of their nostrils) were collected, totaling 140 samples [94]. From these samples, 63 isolates of S. aureus were obtained, corresponding to $32.6 \%$ of the nasal swabs, $30.4 \%$ of the hand swabs, $67.7 \%$ of the milk swabs, and $70.8 \%$ of the cheese swabs. The researchers conducted the diskdiffusion test in agar to check the resistance of the strains. Disks impregnated with erythromycin $(15 \mu \mathrm{g})$, ciprofloxacin $(5 \mu \mathrm{g})$, tetracycline $(30 \mu \mathrm{g})$, gentamicin $(10 \mu \mathrm{g})$, vancomycin $(30 \mu \mathrm{g})$, oxacillin $(1 \mu \mathrm{g})$, and penicillin $(10 \mu \mathrm{g})$ were used. The results showed that $23 \%$ of the isolates had resistance to some antibiotic and 5.5\% were possibly MRSA [94]. Rodrigues et al. [21] analyzed Staphylococcus spp. isolates from three cheese processing plants including samples of raw milk, food handler, and cheese; a total of 100 isolates were characterized of which $88 \%$ were $S$. aureus and mecA gene was identified in six $(6 \%)$ strains. In addition, Brazilian producers of milk derivatives were evaluated for the presence and diversity of $S$. aureus; interestingly, only $7.4 \%$ of the samples was positive for $S$. aureus, and no MRSA was found [89]. Corroborating these results, Silveira-Filho et al. [95] did not detect MRSA in samples of milk and milk derivatives collected in the Northeastern region of the country.

Costa et al. [20] carried out the isolation of $S$. aureus and identification of MRSA. Samples of different types of meats served in 10 hospitals of the city of Salvador, Bahia, were collected, and a total of 114 raw meat samples (30 chicken samples, 30 beef samples, 24 pork samples, and 30 fish 
samples) were analyzed. Of the 114 raw meat samples, $28.1 \%$ were positive for MRSA. S. aureus was also isolated from 63 cooked meat samples ( 15 chicken samples, 15 beef samples, 15 pork samples, and 18 fish samples); of these, 9.5\% contained MRSA. The high prevalence of MRSA in meat, mainly in food prepared for consumption, emphasizes the need for the best food handling practices in hospitals [20], and also for the best practices in the handling of animals.

A survey conducted with 552 milk samples from 15 dairy farms in the state of Paraíba identified 65 samples which tested positive for $S$. aureus, and of these, 20 had MRSA and none isolate was resistant to vancomycin [96]; in this case, $30.7 \%$ of the samples had MRSA. Recently, an outbreak of bovine mastitis caused by $S$. aureus in a Brazilian dairy farm was analyzed. Guimarães et al. [97] evaluated 115 milk samples from the herd affected by the disease and found that $53 \%$ of the samples had Staphylococcus spp.; of these, $98.4 \%$ were positive for $S$. aureus, and the presence of the mecA gene was identified in $48.3 \%$ of the $S$. aureus isolates. In total, $12.2 \%$ of the cases of mastitis were caused by MRSA; this high percentage raises concern for animal and human health [97]. On the other hand, Silva et al. [31] identified methicillin-sensitive $S$. aureus in milk samples from cows with mastitis. They obtained 56 MSSA isolates from 1484 milk samples of 518 cows in 11 different farms located in Brazil. In the same study, the researchers conducted molecular characterization, gene research, reinforcing the importance that these instruments have for characterizing S. aureus [31].

Rabello et al. [98] developed a research in the state of Rio de Janeiro in which they identified 227 S. aureus isolates in milk samples of cows with subclinical mastitis, with the exception of two that had clinical mastitis. The samples were collected from 18 herds distributed in 9 cities of Rio de Janeiro from July 2001 to July 2004. PCR analysis was performed to amplify $16 \mathrm{~S}$ rRNA gene for bacteria species identification. The characterization of the strains was important to determine the cause of infection and develop control measures [98].

The study conducted by Monte [65] included 110 staphylococci isolated from 147 samples of 21 semi-extensive dairy farms in the Northeast of Brazil. Of these, 40 of them were $S$. aureus, most of them isolated from milk samples, two of which presented the mecA gene, indicative of MRSA. The other 70 isolates were coagulase negative, most of them from swabs (52.4\%) and environmental samples (29.5\%), 14 of these isolates were positive mecA.

Alves et al. [90] collected 64 samples from three dairy products from Minas Frescal artisanal cheese production located in the Midwest region of Goiás, Brazil. These samples include processing environments, raw materials, and final product. Those were confirmed by PCR amplification of the 16S rRNA gene, MLST, and antimicrobial susceptibility test, 33 isolates were confirmed as $S$. aureus, but only one was identified as MRSA (strain isolated from brine).
Given the above, it is possible to verify that the incidence of S. aureus and MRSA is common in food and in the food production chain, and that researches are still required for a better understanding of the distribution of MRSA and its diversity, with emphasis on analyses that allow verification of similarity of the strains and thus determinate or suggest their origin and, consequently, indicate preventive and control measures.

\section{Conclusion}

The use of antibiotics, and more specifically the indiscriminate use of antibiotics, in the treatment of infections caused by Staphylococcus generated a very serious public health problem: the resistance of Staphylococcus spp. to antibiotics. In this review, information about MRSA was gathered from studies published around the world. Herein, the incidence of MRSA in food samples, food handlers, food-producing animals, and food processing environments was presented. The situation is critical since VISA and VRSA are being reported in the treatment of infections caused by MRSA, revealing the difficulty to treat infections and the need for new antibiotics. The need for caution in the use of antibiotics in both human and animal health is emphasized.

In Brazil, researches support that $S$. aureus is widely present in the food production chain and in final products, thus representing a potential risk to public health. However, researches on MRSA in food in certain regions of the country are still scarce, which may be concealing a reality that is different from the one presented here. Finally, it is worth noting that studies on MRSA are still required because of their significance to public health.

Funding information This work was financially supported by grants from CAPES - Programa de Excelência Acadêmica (PROEX) (grant numbers 23038.000795/2018-61).

\section{Compliance with ethical standards}

Conflict of interest The authors declare that they have no conflict of interest.

\section{References}

1. Kim YS, Lee SH, Kim SH, Joo Y, Bahk GJ (2015) Investigation of the experience of foodborne illness and estimation of the incidence of foodborne disease in South Korea. Food Control 47:226-230. https://doi.org/10.1016/j.foodcont.2014.07.015

2. Gutiérrez D, Rodríguez-Rubio L, García P, Billington C, Premarante A, Rodríguez A, Martínez B (2016) Phage sensitivity and prophage carriage in Staphylococcus aureus isolated from foods in Spain and New Zealand. Int J Food Microbiol 230:1620. https://doi.org/10.1016/j.jifoodmicro.2016.04.019 
3. Kroning IS, Iglesias MA, Sehn CP, Gandra TKV, Mata MM, da Silva WP (2016) Staphylococcus aureus isolated from handmade sweets: biofilm formation, enterotoxigenicity and antimicrobial resistance. Food Microbiol 58:105-111. https://doi.org/10.1016/j.fm. 2016.04.001

4. Gutiérrez D, Delgado S, Vázquez-Sánchez D et al (2012) Incidence of Staphylococcus aureus and analysis of associated bacterial communities on food industry surfaces. Appl Environ Microbiol 78(24):8547-8554. https://doi.org/10.1128/AEM.02045-12

5. Wattinger L, Stephan R, Layer F, Johler S (2012) Comparison of Staphylococcus aureus isolates associated with food intoxication with isolates from human nasal carriers and human infections. Eur J Clin Microbiol Infect Dis 31:455-464

6. Crago B, Ferrato C, Drews SJ, Svenson LW, Tyrrell G, Louie M (2012) Prevalence of Staphylococcus aureus and methicillinresistant $S$. aureus (MRSA ) in food samples associated with foodborne illness in Alberta , Canada from 2007 to 2010. Food Microbiol 32:202-205. https://doi.org/10.1016/j.fm.2012.04.012

7. Oniciuc EA, Ariza-Miguel J, Bolocan AS et al (2015) Foods from black market at EU border as a neglected route of potential methicillin-resistant Staphylococcus aureus transmission. Int J Food Microbiol 209:34-38. https://doi.org/10.1016/j.ijfoodmicro. 2014.11.015

8. Figueiredo AMS, Ferreira FA (2014) The multifaceted resources and microevolution of the successful human and animal pathogen methicillin-resistant Staphylococcus aureus. Mem Inst Oswaldo Cruz 109(3):265-278. https://doi.org/10.1590/0074-0276140016

9. Kluytmans JAJW (2010) Methicillin-resistant Staphylococcus aureus in food products: cause for concern or case for complacency? Eur Soc Clin Microbiol Infect Dis 16:11-15. https://doi.org/10. 1111/j.1469-0691.2009.03110.x

10. Graveland H, Duim B, van Duijkeren E, Heederik D, Wagenaar JA (2011) Livestock-associated methicillin-resistant Staphylococcus aureus in animals and humans. Int J Med Microbiol 301:630634. https://doi.org/10.1016/j.ijmm.2011.09.004

11. Farias ALN, Frota CC (2015) Staplylococcus aureus (MRSA and CA-MRSA strains) in South America: comparative review to emergence of strains in North America and worldwide. Rev Med 55(2): $39-45$

12. Thurlow LR, Joshi GS, Richardson AR (2012) Virulence strategies of the dominant USA300 lineage of community associated methicillin-resistant Staphylococcus aureus (CA-MRSA). FEMS Immnunol Med Microbiol 65(1):5-22. https://doi.org/10.1111/j. 1574-695X.2012.00937.x.Virulence

13. DeLeo FR, Otto M, Kreiswirth BNB, Chambers HFH (2010) Community-associated meticillin-resistant Staphylococcus aureus. Lancet. 375(9725):1557-1568. https://doi.org/10.1016/S01406736(09)61999-1.Community-associated

14. Chambers HF, Deleo FR (2010) Waves of resistance: Staphylococcus aureus in the Antibiotic Era. Nat Rev Microbiol 7(9):629-641. https://doi.org/10.1038/nrmicro2200.Waves

15. Sergelidis D, Angelidis AS (2017) Methicillin-resistant Staphylococcus aureus: a controversial food-borne pathogen. Lett Appl Microbiol 64:409-418. https://doi.org/10.1111/lam.12735

16. Castro A, Santos C, Meireles H, Silva J, Teixeira P (2016) Food handlers as potential sources of dissemination of virulent strains of Staphylococcus aureus in the community. J Infect Public Health. 9: 153-160. https://doi.org/10.1016/j.jiph.2015.08.001

17. Lee BY, Singh A, David MZ, Bartsch SM, Slayton RB, Huang SS, Zimmer SM, Potter MA, Macal CM, Lauderdale DS, Miller LG, Daum RS (2012) The economic burden of community-associated methicillin-resistant Staphylococcus aureus (CA-MRSA). Clin Microbiol Infect 19(6):528-536. https://doi.org/10.1111/j.14690691.2012.03914.x

18. Ishitobi N, Wan TW, Khokhlova OE, Teng LJ, Yamamori Y, Yamamoto T (2018) Fatal case of ST8/SCCmecIVl community- associated methicillin-resistant Staphylococcus aureus infection in Japan. New Microbes New Infect 26(day 1):30-36. https://doi.org/ 10.1016/j.nmni.2018.08.004

19. Van Cleef BA, Verkade EJM, Wulf MW et al (2010) Prevalence of livestock-associated MRSA in communities with high pig-densities in the Netherlands. PLoS One 5(2):1-5. https://doi.org/10.1371/ journal.pone. 0009385

20. Costa WLR, Ferreira J (2015) dos S, Carvalho JS, Cerqueira ES, Oliveira LC, Almeida RC de C. Methicillin-resistant Staphylococcus aureus in raw meats and prepared foods in public hospitals in Salvador, Bahia, Brazil. J Food Sci 80(1):M147-M150. https://doi.org/10.1111/1750-3841.12723

21. Rodrigues MX, Silva NCC, Trevilin JH, Cruzado MMB, Mui TS, Duarte FRS, Castillo CJC, Canniatti-Brazaca SG, Porto E (2017) Molecular characterization and antibiotic resistance of Staphylococcus spp. isolated from cheese processing plants. J Dairy Sci 100(7):5167-5175

22. ANVISA (2007) Antimicrobianos - Bases Teóricas e Uso Clínico. Agência Nac Vigilância Sanitária:1. http://www.anvisa.gov.br/ servicosaude/controle/rede_rm/cursos/rm_controle/opas_web/ modulo1/lactamicos.htm\#

23. Boopathy R (2017) Presence of methicillin resistant Staphylococcus aureus ( MRSA ) in sewage treatment plant. Bioresour Technol:1-5. https://doi.org/10.1016/j.biortech.2017. 02.093

24. Andreoletti O, Budka H, Buncic S et al (2009) Assessment of the public health significance of meticillin resistant Staphylococcus aureus (MRSA ) in animals and foods. EFSA J 993:1-73

25. Guzmán-Blanco M, Mejía C, Isturiz R et al (2009) Epidemiology of meticillin-resistant Staphylococcus aureus (MRSA) in Latin America. Int J Antimicrob Agents 34:304-308. https://doi.org/10. 1016/j.ijantimicag.2009.06.005

26. Akpaka PE, Roberts R, Monecke S (2016) Molecular characterization of antimicrobial resistance genes against Staphylococcus aureus isolates from Trinidad and Tobago. J Infect Public Health.: 1-8. https://doi.org/10.1016/j.jiph.2016.05.010

27. Mediavilla JR, Chen L, Mathema B, Kreiswirth BN (2012) Global epidemiology of community-associated methicillin resistant Staphylococcus aureus (CA-MRSA). Curr Opin Microbiol 15: 588-595. https://doi.org/10.1016/j.mib.2012.08.003

28. Potel C, Rey S, Otero S, Rubio J, Álvarez M (2016) Molecular characterization and clonal diversity of meticillin-resistant Staphylococcus aureus isolated from the community in Spain: emergence of clone sequence type 72. J Hosp Infect:1-4. https:// doi.org/10.1016/j.jhin.2016.03.012

29. Klevens RM, Edwards JR, Tenover FC, Mcdonald LC, Horan T, Gaynes R (2006) Changes in the epidemiology of methicillinresistant Staphylococcus aureus in intensive care units in US hospitals, 1992 - 2003. Clin Infect Dis 42:389-391. https://doi.org/10. 1086/499367

30. Cosgrove S, Sakoulas G, Perencevich E, Schwaber M, Karchmer A, Carmeli Y (2003) Comparison of mortality associated with methicillin resistant and methicillin susceptible Staphylococcus aureus bacteremia: a meta-analysis. Clin Infect Dis 36(1):53-59. https://doi.org/10.1086/345476

31. Silva NCC, Guimarães FF, Manzi MP, Budri PE, Gómez-Sanz E, Benito D, Langoni H, Rall VLM, Torres C (2013) Molecular characterization and clonal diversity of methicillin-susceptible Staphylococcus aureus in milk of cows with mastitis in Brazil. J Dairy Sci 96(11):6856-6862

32. Wang T, Zhang Z, Li Y, Xie G (2015) Amplified electrochemical detection of mecA gene in methicillin-resistant Staphylococcus aureus based on target recycling amplification and isothermal strand-displacement polymerization reaction. Sensors Actuators B 221:148-154. https://doi.org/10.1016/j.snb.2015.06.057 
33. Lin J, Lin D, Xu P et al (2016) Non-hospital environment contamination with Staphylococcus aureus and methicillin-resistant Staphylococcus aureus: proportion meta-analysis and features of antibiotic resistance and molecular genetics. Environ Res 150: 528-540. https://doi.org/10.1016/j.envres.2016.06.040

34. Smith TC (2015) Livestock-associated Staphylococcus aureus: the United States experience. PLoS Pathog 11(2):1-8. https://doi.org/ 10.1371/journal.ppat.1004564

35. Mulvey MR, MacDougall L, Cholin B, Horsman G, Fidyk M, Woods S (2005) Community-associated methicillin-resistant Staphylococcus aureus, Canada. Emerg Infect Dis 11(6):844-850. https://doi.org/10.3201/eid1106.041146

36. Witte W (2009) Community-acquired methicillin-resistant Staphylococcus aureus: what do we need to know? Clin Microbiol Infect 15(SUPPL. 7):17-25. https://doi.org/10.1111/j. 1469-0691.2009.03097.x

37. Graveland H, Van Duijkeren E, Van Nes A et al (2009) Evaluation of isolation procedures and chromogenic agar media for the detection of MRSA in nasal swabs from pigs and veal calves. Vet Microbiol 139: 121-125. https://doi.org/10.1016/j.vetmic.2009.05.019

38. Van Den Eede A, Martens A, Lipinska U, Struelens M (2009) High occurrence of methicillin-resistant Staphylococcus aureus ST398 in equine nasal samples. Vet Microbiol 133:138-144. https://doi.org/ 10.1016/j.vetmic.2008.06.021

39. Witte W, Strommenger B, Stanek C, Cuny C (2007) Methicillinresistant Staphylococcus aureus ST398 in humans and animals, Central Europe. Emerg Infect Dis 13(2):255-258

40. Caggiano G, Dambrosio A, Ioanna F, Balbino S, Barbuti G, de Giglio O, Diella G, Lovero G, Rutigliano S, Scarafile G, Baldassarre A, Vimercati L, Musti M, Montagna MT (2016) Prevalence and characterization of methicillin- resistant Staphylococcus aureus isolates in food industry workers. Ann Ig 28:8-14. https://doi.org/10.7416/ai.2016.2080

41. Hirvonen JJ (2014) The use of molecular methods for the detection and identification of methicillin-resistant Staphylococcus aureus. Biomark Med 8(9):1115-1125. https://doi.org/10.2217/bmm.14.60

42. Börjesson S, Melin S, Matussek A, Lindgren P-E (2009) A seasonal study of the mecA gene and Staphylococcus aureus including methicillin-resistant $S$. aureus in a municipal wastewater treatment plant. Water Res 43:925-932. https://doi.org/10.1016/j.watres. 2008.11.036

43. Chambers HF (2001) The changing epidemiology of Staphylococcus aureus? Emerg Infect Dis 7(2):178-182. https:// doi.org/10.3201/eid0702.010204

44. Peacock SJ, Paterson GK (2015) Mechanisms of methicillin resistance in Staphylococcus aureus. Annu Rev Biochem 84:586-601. https://doi.org/10.1146/annurev-biochem-060614-034516

45. Wan MT, Chou CC (2014) Spreading of B-lactam resistance gene (mecA) and methicillin-resistant Staphylococcus aureus through municipal and swine slaughterhouse wastewaters. Water Res 64: 288-295. https://doi.org/10.1016/j.watres.2014.07.014

46. García-Álvarez L, Holden MTG, Lindsay H, Webb CR, Brown DF, Curran MD, Walpole E, Brooks K, Pickard DJ, Teale C, Parkhill J, Bentley SD, Edwards GF, Girvan EK, Kearns AM, Pichon B, Hill RL, Larsen AR, Skov RL, Peacock SJ, Maskell DJ, Holmes MA (2011) Meticillin-resistant Staphylococcus aureus with a novel mecA homologue in human and bovine populations in the UK and Denmark: a descriptive study. Lancet Infect Dis 11:595-603. https://doi.org/10.1016/S1473-3099(11)70126-8

47. Van Duijkeren E, Hengeveld PD, Albers M et al (2014) Prevalence of methicillin-resistant Staphylococcus aureus carrying mecA or mecC in dairy cattle. Vet Microbiol 171:364-367

48. Ito T, Okuma K, Ma XX, Yuzawa H, Hiramatsu K (2003) Insights on antibiotic resistance of Staphylococcus aureus from its whole genome: genomic island SCC. Drug Resist Updat 6:41-52. https:// doi.org/10.1016/S1368-7646(03)00003-7
49. Aguilar JL, Varshney AK, Wang X, Stanford L, Scharff M, Fries BC (2014) Detection and measurement of staphylococcal enterotoxin-like K (SEl-K) secretion by Staphylococcus aureus clinical isolates. J Clin Microbiol 52(7):2536-2543. https://doi. org/10.1128/JCM.00387-14

50. Otto M (2010) Basis of virulence in community-associated methicillin-resistant Staphylococcus aureus. Annu Rev Microbiol 64: 143-162. https://doi.org/10.1146/annurev.micro.112408.134309

51. Doulgeraki AI, Di Ciccio P, Ianieri A, Nychas G-JE (2016) Methicillin-resistant food-related Staphylococcus aureus: a review of current knowledge and biofilm formation for future studies and applications. Res Microbiol:1-15. https://doi.org/10.1016/j.resmic. 2016.08.001

52. Baig S, Johannesen TB, Overballe-Petersen S, Larsen J, Larsen AR, Stegger M (2018) Novel SCCmec type XIII (9A) identified in an ST152 methicillin-resistant Staphylococcus aureus. Infect Genet Evol 61:74-76. https://doi.org/10.1016/j.meegid.2018.03.013

53. Abbasian S, Farahani NN, Mir Z, Alinejad F, Haeili M, Dahmardehei M, Mirzaii M, Khoramrooz SS, Nasiri MJ, DarbanSarokhalil D (2018) Genotypic characterization of Staphylococcus aureus isolated from a burn centre by using agr, spa and SCCmec typing methods. New Microbes New Infect 26:15-19. https://doi. org/10.1016/j.nmni.2018.08.001

54. Monecke S, Slickers P, Gawlik D, Müller E, Reissig A, RuppeltLorz A, de Jäckel SC, Feßler AT, Frank M, Hotzel H, Kadlec K, Jatzwauk L, Loncaric I, Schwarz S, Schlotter K, Thürmer A, Wendlandt S, Ehricht R (2018) Variability of SCC mec elements in livestock-associated CC398 MRSA. Vet Microbiol 217:36-46. https://doi.org/10.1016/j.vetmic.2018.02.024

55. IWG-SCC (2009) Classification of staphylococcal cassette chromosome mec (SCCmec): guidelines for reporting novel SCCmec elements. Antimicrob Agents Chemother 53(12):4961-4967. https:// doi.org/10.1128/AAC.00579-09

56. IWG-SCC (2014) International Working Group on the Staphylococcal Cassette Chromosome elements. http://www. sccmec.org. Accessed 29 October 2018

57. Deurenberg RH, Vink C, Kalenic S, Friedrich AW, Bruggeman CA, Stobberingh EE (2007) The molecular evolution of methicillinresistant Staphylococcus aureus. Clin Microbiol Infect 13:222235. https://doi.org/10.1111/j.1469-0691.2006.01573.x

58. Fasihi Y, Kiaei S, Kalantar-Neyestanaki D (2017) Characterization of SCCmec and spa types of methicillin-resistant Staphylococcus aureus isolates from health-care and community-acquired infections in Kerman. Iran J Epidemiol Glob Health 7:263-267. https://doi.org/10.1016/j.jegh.2017.08.004

59. Basanisi MG, La Bella G, Nobili G, Franconieri I, La Salandra G (2017) Genotyping of methicillin-resistant Staphylococcus aureus (MRSA) isolated from milk and dairy products in South Italy. Food Microbiol 62:141-146. https://doi.org/10.1016/j.fm.2016.10.020

60. Herrera FC, García-López M-L, Santos JA (2016) Short communication: characterization of methicillin-resistant Staphylococcus aureus isolated from raw milk fresh cheese in Colombia. J Dairy Sci 99(10):7872-7876. https://doi.org/10.3168/jds.2016-11322

61. Kang K-M, Park J, Hyun S, Yang S-J (2019) Potential role of host defense antimicrobial peptide resistance in increased virulence of health care-associated MRSA strains of sequence type ( ST ) 5 versus livestock-associated and community-associated MRSA strains of ST72. Comp Immunol Microbiol Infect Dis 62:13-18. https://doi.org/10.1016/j.cimid.2018.11.012

62. Parvez MAK, Ferdous RN, Rahman MS, Islam S (2018) Healthcare-associated ( HA ) and community-associated ( CA ) methicillin resistant Staphylococcus aureus ( MRSA ) in Bangladesh - Source, diagnosis and treatment. J Genet Eng Biotechnol. 16:473-478. https://doi.org/10.1016/j.jgeb.2018.05. 004 
63. Omara ST (2017) MIC and MBC of honey and gold nanoparticles against methicillin-resistant ( MRSA ) and $S$. aureus isolated from contagious bovine clinical mastitis. J Genet Eng Biotechnol 15: 219-230. https://doi.org/10.1016/j.jgeb.2017.02.010

64. Kraushaar B, Fetsch A (2014) First description of PVL-positive methicillin-resistant Staphylococcus aureus ( MRSA ) in wild boar meat. Int J Food Microbiol 186:68-73. https://doi.org/10.1016/j. ijfoodmicro.2014.06.018

65. Monte DFM, Júnior WDL, Abley M, Gebreyes WA, de Oliveira CJB (2018) Antimicrobial resistance and genotypic relatedness of environmental staphylococci in semi-extensive dairy farms. Vet Anim Sci 6:103-106. https://doi.org/10.1016/j.vas.2018.07.007

66. Alkharsah KR, Rehman S, Alnimr A, Diab A, Hawwari A, Tokajian S (2018) Molecular typing of MRSA isolates by spa and PFGE. J King Saud Univ Sci. https://doi.org/10.1016/j.jksus.2018. 07.018

67. Tenhagen B, Alt K, Pfefferkorn B, Wiehle L, Käsbohrer A, Fetsch A (2018) Short communication : methicillin-resistant Staphylococcus aureus in conventional and organic dairy herds in Germany. J Dairy Sci 101(4):3380-3386. https://doi.org/10.3168/ jds.2017-12939

68. Thiran E, Di Ciccio PA, Graber HU, Zanardi E, Ianieri A, Hummerjohann J (2018) Biofilm formation of Staphylococcus aureus dairy isolates representing different genotypes. J Dairy Sci 101:1000-1012. https://doi.org/10.3168/jds.2017-13696

69. Rabaan AA, Bazzi AM (2017) Variation in MRSA identification results from different generations of Xpert MRSA real-time PCR testing kits from nasal swabs. J Infect Public Health 10:799-802. https://doi.org/10.1016/j.jiph.2017.01.007

70. Reynaga E, Torres C, Garcia-Nuñez M et al (2017) Clinical impact and prevalence of MRSA CC398 and differences between MRSATet R and MRSA-Tet $\mathrm{S}$ in an area of Spain with a high density of pig farming : a prospective cohort study *. Clin Microbiol Infect 23(678):1-4. https://doi.org/10.1016/j.cmi.2017.03.019

71. Gómez NC, Abriouel H, Grande MJ, Pulido RP, Gálvez A (2013) Combined treatments of enterocin AS-48 with biocides to improve the inactivation of methicillin-sensitive and methicillin-resistant Staphylococcus aureus planktonic and sessile cells. Int J Food Microbiol 163:96-100. https://doi.org/10.1016/j.ijfoodmicro.2013. 02.018

72. Ariza-Miguel J, Oniciuc EA, Sanz I, Fernández-Natal I, Hernández M, Rodríguez-Lázaro D (2015) Evaluation of two commercially available chromogenic media for confirmation of methicillinresistant Staphylococcus aureus from human, animal, and food samples. Int J Food Microbiol 209:26-28. https://doi.org/10.1016/ j.ijfoodmicro.2015.05.004

73. Rodríguez-Lázaro D, Ariza-Miguel J, Diez-Valcarce M, FernándezNatal I, Hernández M, Rovira J (2015) Foods confiscated from nonEU flights as a neglected route of potential methicillin-resistant Staphylococcus aureus transmission. Int J Food Microbiol 209: 29-33. https://doi.org/10.1016/j.ijfoodmicro.2014.08.016

74. Erskine RJ, Walker RD, Bolin CA, Bartlett PC, White DG (2002) Trends in antibacterial susceptibility of mastitis pathogens during a seven-year period. J Dairy Sci 85(5):1111-1118. https://doi.org/10. 3168/jds.S0022-0302(02)74172-6

75. Makovec JA, Ruegg DPL (2003) Antimicrobial resistance of bacteria isolated from dairy cow milk samples submitted for bacterial culture: 8,905 samples (1994-2001). Sci Reports Retrosp Study 222(11):1582-1589. https://doi.org/10.2460/javma.2003.222.1582

76. Kitai S, Shimizu A, Kawano J et al (2005) Characterization of methicillin-resistant Staphylococcus aureus isolated from retail raw chicken meat in Japan. J Vet Med Sci 67(1):107-110. https:// doi.org/10.1292/jvms.67.107

77. Anderson KL, Lyman RL, Bodeis-Jones SM, White DG (2006) Genetic diversity and antimicrobial susceptibility profiles among mastitis-causing Staphylococcus aureus isolated from bovine milk samples. Am J Vet Res 67(7):1185-1191. https://doi.org/10.2460/ ajvr.67.7.1185

78. Quddoumi SS, Bdour SM, Mahasneh AM (2006) Isolation and characterization of methicillin-resistant Staphylococcus aureus from livestock and poultry meat. Ann Microbiol 56(2):155-161

79. Van Loo IHM, Diederen BMW, Savelkoul PHM et al (2007) Methicillin-resistant Staphylococcus aureus in meat products, the Netherlands. Emerg Infect Dis 13(11):1753-1755. https://doi.org/ 10.3201/eid1311.070358

80. Normanno G, Corrente M, La Salandra G et al (2007) Methicillinresistant Staphylococcus aureus (MRSA) in foods of animal origin product in Italy. Int J Food Microbiol 117:219-222. https://doi.org/ 10.1016/j.ijfoodmicro.2007.04.006

81. Lozano C, López M, Gómez-Sanz E, Ruiz-Larrea F, Torres C, Zarazaga M (2009) Detection of methicillin-resistant Staphylococcus aureus ST398 in food samples of animal origin in Spain. J Antimicrob Chemother 64(4):1325-1346. https://doi.org/ 10.1093/JAC/DKP378

82. de Boer E, Zwartkruis-Nahuis JTM, Wit B, Huijsdens XW, de Neeling AJ, Bosch T, van Oosterom R, Vila A, Heuvelink AE (2009) Prevalence of methicillin-resistant Staphylococcus aureus in meat. Int J Food Microbiol 134:52-56. https://doi.org/10.1016/ j.ijfoodmicro.2008.12.007

83. FeBler AT, Kadlec K, Hassel M et al (2011) Characterization of methicillin-resistant Staphylococcus aureus isolates from food and food products of poultry origin in Germany. Appl Environ Microbiol 77(20):7151-7157. https://doi.org/10.1128/AEM. 00561-11

84. O'Brien AM, Hanson BM, Farina SA et al (2012) MRSA in conventional and alternative retail pork products. PLoS One 7(1):1-6. https://doi.org/10.1371/journal.pone.0030092

85. Sergelidis D, Abrahim A, Papadopoulos T, Soultos N, Martziou E, Koulourida V, Govaris A, Pexara A, Zdragas A, Papa A (2014) Isolation of methicillin-resistant Staphylococcus spp . from readyto-eat fish products. Lett Appl Microbiol 59:500-509. https://doi. org/10.1111/lam.12304

86. Riva A, Borghi E, Cirasola D et al (2015) Methicillin-resistant Staphylococcus aureus in raw milk : prevalence, SCC mec typing , enterotoxin characterization, and antimicrobial resistance patterns. J Food Prot 78(6):1142-1146. https://doi.org/10.4315/0362028X.JFP-14-531

87. Liu H, Li S, Meng L et al (2017) Prevalence, antimicrobial susceptibility, and molecular characterization of Staphylococcus aureus isolated from dairy herds in northern China. J Dairy Sci 100(11): 1-8. https://doi.org/10.3168/jds.2017-13370

88. Thapaliya D, Forshey BM, Kadariya J, Quick MK, Farina S, O' Brien A, Nair R, Nworie A, Hanson B, Kates A, Wardyn S, Smith TC (2017) Prevalence and molecular characterization of Staphylococcus aureus in commercially available meat over a one-year period in Iowa, USA. Food Microbiol 65:122-129. https://doi.org/10.1016/j.fm.2017.01.015

89. Dittmann KK, Chaul LT, Lee SHI et al (2017) Staphylococcus aureus in some Brazilian dairy industries : changes of contamination and diversity. Front Microbiol 8:1-12. https://doi.org/10.3389/ fmicb.2017.02049

90. Alves VF, Niño-Arias FC, Pitondo-Silva A et al (2018) Molecular characterisation of Staphylococcus aureus from some artisanal Brazilian dairies. Int Dairy J 85:247-253

91. SVS (2019) Surtos de Doenças Transmitidas por Alimentos no Brasil. Ministério da Saúde Secr Vigilância em Saúde:01-14

92. Soares LS, Almeida RCC, Cerqueira ES, Carvalho JS, Nunes IL (2012) Knowledge, attitudes and practices in food safety and the presence of coagulasepositive staphylococci on hands of food handlers in the schools of Camaçari, Brazil. Food Control 27:206-213. https://doi.org/10.1016/j.foodcont.2012.03.016 
93. Ferreira JS, Costa WLR, Cerqueira ES, Carvalho JS, Oliveira LC, Almeida RCC (2014) Food handler-associated methicillin-resistant Staphylococcus aureus in public hospitals in Salvador, Brazil. Food Control. 37:395-400. https://doi.org/10.1016/j.foodcont.2013.09. 062

94. André MCDPB, Campos MRH, Borges LJ, Kipnis A, Pimenta FC, Serafini ÁB (2008) Comparison of Staphylococcus aureus isolates from food handlers, raw bovine milk and Minas Frescal cheese by antibiogram and pulsed-field gel electrophoresis following SmaI digestion. Food Control 19:200-207. https://doi.org/10.1016/j. foodcont.2007.03.010

95. Silveira-Filho VM, Luz IS, Campos APF, Silva WM, Barros MP, Medeiros ES, Freitas MF, Mota RA, Sena MJ, Leal-Balbino TC (2014) Antibiotic resistance and molecular analysis of Staphylococcus aureus isolated from cow's milk and dairy products in Northeast Brazil. J Food Prot 77(4):583-591. https://doi.org/10. 4315/0362-028X

96. Oliveira CJB, Tiao N, de Sousa FGC, de Moura JFP, Santos Filho L, Gebreyes WA (2016) Methicillin-resistant Staphylococcus aureus from Brazilian dairy farms and identification of novel sequence types. Zoonoses Public Health 63:97-105. https://doi.org/ 10.1111/zph.12209

97. Guimarães FF, Manzi MP, Joaquim SF, Richini-Pereira VB, Langoni H (2017) Short communication: outbreak of methicillinresistant Staphylococcus aureus (MRSA)-associated mastitis in a closed dairy herd. J Dairy Sci 100(1):1-5. https://doi.org/10.3168/ jds.2016-11700

98. Rabello RF, Moreira BM, Lopes RMM, Teixeira LM, Riley LW, Castro ACD (2007) Multilocus sequence typing of Staphylococcus aureus isolates recovered from cows with mastitis in Brazilian dairy herds. J Med Microbiol 56:1505-1511. https://doi.org/10.1099/ jmm.0.47357-0

Publisher's note Springer Nature remains neutral with regard to jurisdictional claims in published maps and institutional affiliations. 